\title{
BENTUK IMPLEMENTASI TANGGUNG JAWAB SOSIAL PADA BANK SYARIAH MANDIRI CABANG MATARAM
}

\author{
Anak Agung Istri Pradnyarani Dewi \\ Fakultas Ekonomi dan Bisnis Universitas Warmadewa \\ aipradnyarani@gmail.com \\ Mulyani Damayanti \\ Fakultas Ekonomi dan Bisnis Universitas Brawijaya \\ mulyanidamayanti1@gmail.com
}

\begin{abstract}
Abstrak
Tanggung jawab sosial atau Corporate Sosial Responsibility (selanjutnya disebut CSR) pada perusahaan sedang banyak diperbincangkan. Hal ini dipengaruhi oleh terjadinya peningkatan keingintahuan perusahaan dan instansi-instansi swasta yang ingin melaksanakan program tanggung jawab sosial di dalam perusahaan mereka. Hal yang sama juga berlaku bagi entitas perbankan dan juga perbankan syariah dalam melaksanakan aktivitas tanggung jawab sosialnya. Beberapa penelitian menyebutkan bentuk pelaksanaan tanggung jawab sosial yang dilakukan oleh bank syariah masih dianggap sebagai alat untuk membentuk citra perusahaan semata yang ujungnya akan menguntungkan pihak perusahaan. Kondisi demikian bertolak belakang dengan filosofi perbankan syariah yang berlandaskan prinsip syariah yang mendorong untuk beroperasi dengan landasan moral, etika, dan tanggung jawab sosial. Melalui pendekatan interpretif dengan metode studi kasus, peneliti ingin mendalami bagaimana program tanggung jawab sosial yang digulirkan perbankan syariah tersebut memiliki manfaat yang besar dan sesuai dengan kebutuhan stakeholder. Hasil penelitian menyebutkan bahwa BSM cabang Mataram telah melakukan tanggung jawab sosial yang sumber pendanannya dikelola oleh Laznas (Lembaga Amil Zakat). BSM cabang Mataram bersama Laznas telah melakukan beberapa program tanggung jawab sosial yaitu program Didik Umat, dimana memberikan santunan untuk biaya pendidikan untuk anak yatim dan dhuafa, dan program Simpati Umat dimana BSM dan Laznas mengadakan program bantuan bencana alam Lombok-Sumbawa, pemotongan hewan qurban untuk masyarakat sekitar yang kurang mampu dan perbaikan masjid.
\end{abstract}

Keyword: corporate social responsibility; bank Syariah mandiri, Lembaga amil zakat.

\section{PENDAHULUAN}

Secara umum penggunaan istilah tanggung jawab sosial atau Corporate Sosial Responsibility (selanjutnya disebut CSR) pada perusahaan sedang banyak diperbincangkan. Hal ini dipengaruhi oleh terjadinya peningkatan keingintahuan perusahaan dan instansi-instansi swasta yang ingin melaksanakan program tanggung jawab sosial di dalam perusahaan mereka. Saat ini masalah lingkungan menjadi sorotan dari berbagai pihak yang terkait dengan kualitas hidup masyarakat. Permasalahan lingkungan hidup ini akan semakin disoroti dan menjadi perhatian khusus dari berbagai kalangan, jika hal tersebut diakibatkan karena aktivitas perusahaan.

Dampak dari aktivitas perusahaan tidak hanya dirasakan oleh pihak yang terkait langsung dengan perusahaan namun juga dirasakan oleh lingkungan sosial yang ada di sekitar perusahaan beroperasi. Perusahaan dalam melaksanakan kegiatannya tidak terlepas dari suatu tatanan lingkungan masyarakat, sehingga sebaiknya perusahaan harus memperhatikan kegiatan sosial sebagai kompensasi dari penguasaan sumber daya oleh perusahaan yang terkadang bersifat ekspansif 
dan eksploratif bahkan dapat menimbulkan ketidaknyamanan pada masyarakat sekitarnya.

Praktik tanggung jawab sosial lebih banyak dilakukan oleh perusahaan tambang dan manufaktur. Namun seiring dengan kesadaran tentang pentingnya tanggung jawab sosial menyebabkan tanggung jawab sosial menjadi tren global dengan semakin maraknya kepedulian masyarakat terhadap produkproduk ramah lingkungan dan diproduksi dengan memperhatikan kaidah-kaidah sosial dan prinsip-prinsip hak asasi manusia (Wibsono, 2007).

Pengungkapan informasi tanggung jawab sosial dalam laporan tahunan merupakan salah satu cara perusahaan untuk membangun, mempertahankan, dan melegitimasi kontribusi perusahaan dari sisi ekonomi dan politis (Sayekti \& Wandabio, 2007). Hal yang sama juga berlaku bagi entitas perbankan dan juga perbankan syariah dalam melaksanakan aktivitas tanggung jawab sosialnya. Saat ini industri perbankan juga telah menyebutkan aspek pertanggung jawaban sosial dalam laporan tahunannya walaupun dalam bentuk yang relatif sederhana. Tanggung jawab sosial berlaku untuk semua perusahaan, tidak terkecuali perusahaan perbankan syariah di Indonesia (Prajarto, 2012).

Meutia (2010) berpendapat bahwa Bank Islam atau dikenal juga dengan sebutan bank syariah, merupakan bank yang seharusnya menjalankan kegiatannya berdasarkan prinsip syariah. Faktor utama yang mendasari didirikannya bank syariah adalah adanya keinginan untuk menjalankan sistem perekonomian yang berbasis nilai-nilai dan prinsip syariah. Pelaksanaan program CSR bank Syariah juga bukan hanya untuk memenuhi undang-undang akan tetapi lebih dari itu bahwa tanggung jawab sosial bank syariah dibangun atas dasar falsafah Islam yang kuat untuk menjadi salah satu Lembaga keuangan yang dapat menyejahterakan masyarakat dan berupaya antara menyimbangkan tujuan manajer keuntungan dengan tujuan kemaslahatan sosial lingkungan (Siwar, 2010; Yusuf, 2010; Salim, 2010; Issalih, 2015; Mulawarman dkk, 2018).

Yusuf (2010: 99) mengungkapkan bank syariah memiliki dimensi spiritual yang lebih dominan jika dibandingkan dengan bank konvensional, yaitu nilai-nilai spiritual Islam. Nilai-nilai atau dimensi spiritual ini, tidak hanya menghendaki bisnis non riba namun juga mampu memberikan kesejahteraan bagi masyarakat luas, terutama masayarakat kurang mampu (Meutia, 2010). Hal senada diungkapkan Dusuki (2005) bahwa perbankan syariah diharapkan menunjukkan tingkat tanggung jawab sosial lebih tinggi daripada yang dilakukan oleh bank-bank konvensional karena pada dasarnya bank syariah berdasarkan prinsip syariah untuk beroperasi dengan landasan moral, etika, dan tanggung jawab sosial.

Disisi lain, terdapat pula problem dari segi pelaksanaan tanggung jawab sosial, hingga saat ini program-program tanggung jawab sosial yang dijalankan oleh perusahaan di beberapa perbankan syariah hanya memiliki pengaruh jangka pendek dengan skala terbatas dan belum ada standar yang bersifat baku. Bahkan tanggung jawab sosial seakan ditujukan hanya berlomba untuk meningkatkan reputasi perusahaan yang positif di mata pasar, tetapi berujung pada komersial perusahaan, bukan demi perbaikan kualitas hidup masyarakat dalam jangka panjang dengan community sustainable development model (pengembangan berkelanjutan masyarakat) (Prastowo \& Huda, 2011: 93).

$$
\text { Haniffa dan Hudaib }
$$
menyatakan bahwa salah satu kesempatan untuk menunjukan tanggung jawab dan komitmennya dalam memenuhi kebutuhan umat Islam dan masyarakat secara umum adalah melalui pengungkapan informasi yang relevan dan dapat diandalkan (reliable) dalam laporan tahunan melalui pengkungkapan tanggung jawab sosial syariah dapat memberikan informasi sejauh mana ia 
memenuhi fungsi sebagai sarana untuk meningkatkan kesejahteraan masyarakat. Tidak seperti bank konvesnsional yang cenderung menekankan pada pengungkapan laba, penilaian resiko dan aspek non sosial lainnya, bank syariah harus mengungkapkan informasi yang penting bagi pengguna laporan mereka, guna pengambilan keputusan untuk menunjukkan tanggung jawab mereka pada Tuhan dan masyarakat.

Seperti hasil penelitian dari Haniffa dan Hudaib (2007) atas laporan tahunan tujuh bank syariah di dunia menunjukkan bahwa banyak sekali tidak kesesuaian antara informasi yang diungkapkan di laporan tahunan dengan nilai etika bisnis syariah. Ketidaksesuaian ini diantaranya berkaitan dengan empat dimensi, yaitu komitmen terhadap masyarakat, pengungkapan visi dan misi perusahaan, kontribusi dan manajemen zakat, charity dan pinjaman kebajikan serta informasi mengenai manajemen. Temuan ini cukup menyentak karena bank syariah sebagai institusi ekonomi dan sosial diharapkan mengkomunikasikan lebih banyak dimensi untuk merefleksikan akuntabilitas dan keadilan tidak hanya kepada masyarakat melainkan juga kepada Tuhan.

Peneliti lainnya, Sairally (2005) mengevaluasi pelaksanaan tanggung jawab sosial pada 250 lembaga keuangan Islam di dunia. Hasilnya adalah $87,5 \%$ lembaga keuangan mengalokasikan dana yang sedikit untuk menjalankan tanggung jawab sosial. Indikasinya adalah dana yang sedikit untuk melaksanakan tanggung jawab sosial menunjukkan bahwa pelaksanaan tanggung jawab sosial pada Lembaga kenuangan bank syariah di dunia masih sangat rendah.

Erwanda (2012) mendalami tentang bentuk tanggung jawab dan pelaporan organisasi perbankan BNI syariah terhadap aspek sosial, ekonomi, lingkungan serta aspek religius yang diharapkan dapat memberikan manfaat positif bagi perbankan syariah. Namun, hasil penelitian Erwanda menyebutkan bahwa BNI syariah hanya melaksanakan tanggung jawab sosial pada aspek sosial, khususnya pendidikan. Aspek ekonomi dan lingkungan kurang mendapat perhatian perbankan karena belum ada standar yang mengatur tanggung jawab terhadap ekonomi maupun lingkungan.

Penelitian Isnawati menganalisis tentang bagaimana pengungkapan tanggung jawab sosial pada laporan tahunan 3 perbankan syariah, yakni PT. Bank Muamalat Indonesia, PT. Bank Mega Syariah dan PT. May bank Syariah Indonesia 2014-2016. Isnawati (2018) memperoleh hasil penelitian yang menyatakan bahwa pengungkapan lebih dominan pada 'kinerja ekonomi', 'pelatihan dan pendidikan karyawan' karena hal ini masih dalam lingkup internal perusahaan sehingga belum terlihat kontribusinya untuk pemangku kepentingan yang berada di luar perusahaan.

Selain itu, laporan tahunan mereka lebih diajukan pada pemegang saham yang fokus pada keuntungan dari pada kelompok yang lebih luas dari pemangku kepentingan di masyarakat. Hal ini serupa dengan penelitian oleh penelitian Kamla (2007) pada Arab Middle East yang hasilnya sama dengan penelitian di UK yang menyatakan bahwa rendahnya kualitas pelaporan lingkungan atau sosial disebabkan oleh banyaknya pengungkapan di UK yang berkaitan dengan pengembangan kesan/image perusahaan.

Dari beberapa hasil penelitian di atas, dapat disimpulkan bahwa bentuk pelaksanaan tanggung jawab sosial yang dilakukan oleh perusahaan khususnya bank syariah masih dianggap sebagai alat untuk membentuk citra perusahaan semata yang ujungnya akan menguntungkan pihak perusahaan. Pengungkapan tanggung jawab sosial masih dianggap sebagai pelengkap dalam laporan tahunan yang dirilis oleh perusahaan. Sehingga apa yang menjadi tanggung jawab perusahaan kepada lingkungan dan sosial masih terabaikan.

Kondisi demikian bertolak belakang dengan filosofi perbankan syariah yang berlandaskan prinsip syariah yang mendorong 
untuk beroperasi dengan landasan moral, etika, dan tanggung jawab sosial. Anto \& Astuti (2008) menjelaskan bahwa bank syariah harus mengimbangi hak-hak dari semua stakeholders berdasarkan kewajaran, martabat, keadilan, memastikan distribusi kekayaan yang adil, meningkatkan moral, meningkatkan produktifitas, dan juga meningkatkan distribusi kekayaan di dalam masyarakat.

Dari beberapa penelitian tersebut yang membahas mengenai tanggung jawab sosial, lebih menganalisis dari sisi perusahaan sebagai pemberi program tanggung jawab sosial dan belum ada yang membahas pelaksanaan tanggung jawab sosial khususnya pada perbankan syariah dari sisi stakeholder. Hal ini menarik karena masih sedikitnya penelitian yang membahas tentang pelaksanaan tanggung jawab sosial perbankan syariah dari sisi stakeholder. Bagaimana program tanggung jawab sosial yang digulirkan perbankan syariah tersebut memiliki manfaat yang besar dan sesuai dengan kebutuhan stakeholder.

Oleh sebab itu penelitian ini lebih memfokuskan pelaksanaan tanggung jawab sosial khususnya yang dari sisi stakeholder, agar tujuan tanggung jawab sosial untuk meningkatkan kesejahtraan sosial lingkungannya benar-benar sesuai dengan kebutuhan masyarakat yang menjadi sasaran program tanggung jawab sosial perbankan syariah. Selain itu, penting adanya praktik tanggung jawab sosial yang mengacu pada nilai-nilai Islam, terlebih masyarakat NTB sebagian besar beragama Islam dan menjunjung tinggi nilai-nilai keislaman, maka penelitian ini dimaksudkan untuk memahami bagaimana praktik pelaksanaan tanggung jawab sosial yang diberikan bank mandiri syariah cabang Mataram.

\section{METODE PENELITIAN}

Penelitian ini mengunakan paradigma interpretif dengan metode studi kasus. Peneliti menggunakan metode studi kasus karena penelitian dilakukan pada satu program, waktu dan tempat tertentu yaitu pada aktivitas implimentasi program tanggung jawab sosial pada bank syariah mandiri cabang Mataram. Penelitian dimulai dengan mengidentifikasi satu kasus yang spesifik dengan tujuan untuk mendalami bagaimana implimentasi program tanggung jawab sosial pada BSM cabang Mataram. Informan/narasumber dalam penelitian ini akan diwawancarai merupakan staff tanggung jawab sosial BSM dan masyarakat yang dianggap memiliki keterkaitan dengan program tanggung jawab sosial BSM Cabang Mataram.

Tabel 1 Daftar Nama Informan Penelitian

\begin{tabular}{|c|c|c|}
\hline No. & Nama & Jabatan \\
\hline 1 & Intan & Kepala Cabang BSM Mataram \\
\hline 2 & Agus & Penanggung jawab CSR BSM \\
\hline 3 & Yoyo & Pelaksana teknis CSR BSM \\
\hline 4 & Rizal & Pelaksana teknis CSR BSM \\
\hline 5 & Rusdi & Masyarakat Penerima CSR \\
\hline 6 & Samsyul & Masyarakat Penerima CSR \\
\hline 7 & Amaq Amet & Masyarakat Penerima CSR \\
\hline
\end{tabular}

Sumber: Diolah Peneliti (2018)

Informan dipilih menggunakan teknik purposive sampling yang dimana informan yang dipilih telah memenuhi syarat-syarat tertentu. Nama informan tidak dipaparkan secara lengkap atas permintaan informan.
Pemilihan informan di atas telah melalui proses pertimbangan yang sangat matang untuk mendapatkan informasi secara lengkap dan akurat guna membantu peneliti dalam mencapai tujuan penelitian. Analisi data yang digunakan 
mengacu pada analisis dari Miles \& Huberman (1992).

\section{Gambar 1}

Komponen-komponen Analisis Data Model Interaktif

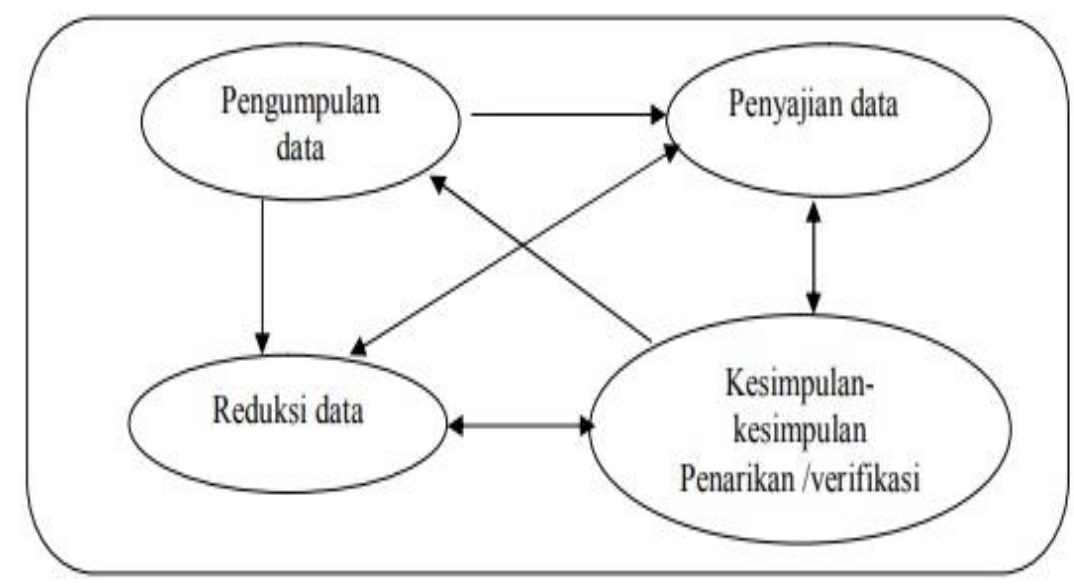

Sumber: Miles \& Huberman (1992)

\section{HASIL DAN PEMBAHASAN}

\section{Sumber Dana Program Tanggung Jawab Sosial (CSR) Pada Bank Syariah Mandiri (BSM) Cabang Mataram}

Para aktor BSM berfokus menghimpun dana CSR bank syariah dari sumber yang terbaik agar fungsi sosial bank syariah dapat tercapai optimal. Penghimpun dana dalam CSR adalah hal yang mutlak dan paling mendasar. Tidak adanya dana sama dengan tidak adanya aktivitas CSR. Suksesnya penghimpunan dana ini sangat dipengaruhi oleh karakter dan kualitas para penghimpunnya. Dalam hal penghimpunan dana, secara periodik BSM menyalurkan dana zakat (dari keuntungan perusahaan, zakat nasabah, zakat pegawai), dana infaq (sumbangan sukarela dari nasabah, pegawai dan masyarakat) dan dana program dana sosial (dari pendapatan non halal BSM, yaitu bunga giro bank konvensional) melalui Laznas BSM. BSM cabang Mataram melaksanakan program tanggung jawab sosial. Program tanggung jawab sosial dilakukan oleh BSM dengan dana yang dikumpulkan dari operasi bisnisnya. Seperti yang diungkapkan Pak Agus selaku Penanggung jawab sosial BSM sebagai berikut:

\begin{abstract}
"Bentuk dana CSR BSM mataram tidak hanya dari laba BSM namun juga dari dana tak bertuan atau biasa sih kita bilangnya Qardhul -hasan atau dana kebajikan".
\end{abstract}

Berdasarkan pernyataan bapak Agus menunjukan bahwa dana CSR tidak hanya bersumber dari laba BSM namun juga dari dana kebajikan (Qordhul hasan). Dana Qordhul hasan bersumber dari denda dan pendapatan non halal dan dana sosial lainnya. Dana kebajikan (Qordhul hasan) adalah dana kebajikan yang dapat disalurkan untuk pembiayaan sosial, yaitu pembiayaan yang pengembaliannya sebesar dana pokoknya saja tanpa bagi hasil dan margin yang bersumber dari 5 sumber bait zakat, infaq, sadaqoh, wakaf, dana denda dan bunga dari bank konvensional (Mais, 2018). Maka harapannya dana kebajikan ini bisa disalurkan dengan efektif dan efisien dengan keragaman program diantaranya dapat disalurkan ke dalam dana bergulir untuk dana yang halal dan hanya untuk umat muslim saja. Sedangkan dana non halal dapat disalurkan ke fasilatas umum dan fasilitas sosial karena bisa dinikmati bukan hanya muslim namun juga non 
muslim seperti jembatan, penerang jalan, perbaikan selokan dan lainnya.

Pernyataan yang senada diungkapan Ibu Yoyo selaku pelaksana teknis CSR BSM cabang Mataram sebagai berikut:

"Ya jadi memang sumber dana kita yah dari dana ZIS dan dana kebajikan (Qordul Hasan), yaitu pertama denda, penerimaan non halal dan dana sosial lainnya. Nah denda ini terkait misalnya kalau nasabah itu telat membayar. Kalau memang nasabah telat membayar itu dalam rangka istilahnya apa yah? Dalam rangka supaya nasabah itu diberikan konsekuensi kalau anda telat bayar yaa kita denda gito loh, cuman memang denda itu tidak bisa kita konsumsi di laporan laba rugi kita, itu kita aplikaskan di apa namanya public fasilities lah yah seperti dana CSR itu, nah itu salah satu sumber denda itu, jadi nasabah-nasabah yang telat membayar. Misal tanggal 20 dia ngga ada dana atau pun ada dana sebagian ya sudah berarti kan dana sebagian masuk mengurangi angsuran pokok dan margin misalnya yang gak bayar itu jadi kena denda gitu dan besaran dendanya adalah sebesar 0,0069\%".

"Bank Konvesional dengan Bank Syariah beda mbak dalam mengalokasikan dana untuk CSRnya. Contohnya begini, pada bank konvesional dana yang diperoleh dari keuntungan atau laba

dipersentasekan untuk
kegiatan CSR, sedangkan pada
Bank Syariah pakai dana yang
berasal dari keuntungan dan
dana non halal yang biasanya
sih disebut dana sosial ya
untuk melakukan CSR itu
menggunakan dana itu"

Berdasarkan pernyataan Ibu Yoyo tersebut menunjukan bahwa dana CSR BSM bersumber dari keuntungan BSM, ZIS dan dana kebajikan. Dana kebajikan yang dimaksud disini adalah denda, non halal dan dana sosial lainnya. Dalam prakteknya Bank Konvensional dan Bank Syariah mempunyai perbedaan dalam mengalokasikan dana yang akan digunakan untuk kegiatan tanggung jawab sosial. Bank Konvensional mempersentase pembagian laba untuk kegiatan tanggung jawab sosial. Sedangkan Bank Syariah dana yang digunakan untuk kegiatan CSR merupakan dana keuntungan dan dana non halal. Pendapatan non halal (bunga giro dari bank konvensional) dan dana sosial lainnya, dalam penyalurannya sebaiknya juga dibedakan penyalurannya mana kegiatan yang dibiayai dari dana denda, mana yang dari pendapaatan non halal dan mana yang ditandai dari dana sosial lainnya karena jika tidak dikategorisasi dan dipilah-pilih dikhawatirkan tidak barokah karena penyaluran didasarkan sumber perolehan agar memenuhi kaidah kebaikan dan sumber yang jelas.

Pada Bank Konvensional, semua denda yang dikenakan kepada nasabah diakui sebagai pendapatan. Besaran denda biasanya merupakan persentase dari nilai angsuran yang dibayar dan dikali dengan jumlah hari keterlambatan. Semakin lama keterlambatan pembayaran angsuran, maka nilai denda akan semakin besar. Sedangkan denda pelunasan dipercepat biasanya merupakan persentase dari sisa outstanding pokok.

Dana tanggung jawab sosial BSM cabang Mataram yang bersumber dari laba perusahaan sebagaimana dijelaskan dalam UU 
No 40 Tahun 2007 dan UU No 25 Tahun 2007. Sedangkan yang bersumber dari dana sosial yang diambil dari ZIS dan dana kebajikan sebagaimana yang telah ditetapkan oleh BSM pusat. Besaran dana sosial tersebut, menurut Turmudi (2018) pada dasarnya sudah ditentukan oleh BSM Pusat berdasarkan kinerja setiap cabang. Pelaksanaan program tanggung jawab sosial di BSM Pusat memiliki 2 sumber dana, yaitu Dana Zakat Infaq Shadaqoh (ZIS) dan Dana Kebajikan (Qordhul Hasan). Dana kebajikan (Qordul Hasan) bersumber dari (1) denda (ta'zir) yang di bebabankan kepada nasabah pembiayaan karena kelalaian dalam memenuhi kewajiban kepada BSM. Besarannya disesuaikan dengan ketentuan internal BSM cabang Mataram. Perbankan Syariah tidak mengakui dana yang berasal dari denda tersebut sebagai pendapatan Bank, sehingga dialokasikan sebagai dana kebajikan; (2) penerimaan non halal, yakni pendapatan bunga yang diperoleh dari investasi, ataupun penempatan dana di bank konvensional yang menerapkan sistem bunga.

Dalam hal ini perbankan syariah memiliki kesempatan untuk menunjukkan tanggung jawab dan komitmennya dalam beroperasi untuk memenuhi kebutuhan umat Islam dan masyarakat secara umum adalah melalui pengungkapan informasi yang relevan dan dapat diandalkan dalam laporan tahunan. Melalui pengungkapan tanggungjawab sosial bank syariah dapat memberikan informasi sejauh mana ia telah memenuhi fungsi sosialnya, yaitu dari mana dana CSR bersumber dan diperuntukan apa saja penggunaannya (Haniffa $\&$ Hudaib, 2004).

Jika dilihat dari kacamata ajaran Islam, program CSR merupakan perwujudan dari ajaran kebajikan yang sangat mulia dan terhormat, baik di sisi manusia maupun Tuhan. Di samping itu konsep CSR juga merupakan implikasi dari ajaran kepemilikan dalam Islam. Allah adalah pemilik mutlak (haqiqiyah), sedangkan manusia hanya sebatas pemilik sementara yang berfungsi sebagai penerima amanah (mandat) (Djakfar, 2012; Djalaluddin, 2014). Konsep CSR dalam Islam lebih ditekankan sebagai bentuk ketakwaan manusia kepada Allah SWT dalam dimensi perusahaan (Siwar \& Hossain, 2009). Terlebih lagi saat ini semua bank syariah mempunyai dana CSR yang bersumber dari dana zakat Qardhul Hasan (dana kebajikan) yaitu dana denda, dana bunga giro (dana non halal), dana sosial lainnya, yang bukan merupakan pendapatan bank dan dikembalikan kemasyarakat yang digunakan untuk kesejahteraan masyarakat.

\section{Bentuk Implementasi Tanggung Jawab Sosial (CSR)}

Mekanisme dalam pelaksanaan program tanggung jawab sosial BSM cabang Mataram, BSM bekerjasama dengan Laznas dan dalam pelaksanaan CSR tersebut harus sesuai dengan program yang ada di Laznas seperti program didik umat, program simpati umat. Dana untuk program CSR BSM cabang Mataram yang bersumber dari laba perusahaan, ZIS (zakat, infak, sadakoh) dan dana kebajikan (denda dan pendapatan non halal). Dana-dana tersebut dihimpun oleh BSM dan dikelola oleh Laznas. Sebagai ungkapkan oleh ibu Yoyo sebagai berikut:

"dalam bank syariah
terutama BSM, kegiatan
tanggung jawab sosial ini
dananya atau untuk
menyalurkan dana untuk
CSR BSM cabang
Mataram dikelola oleh
Laznas".

Dari pernyataan ibu Yoyo menunjukan bahwa mekanisme penyaluran dana untuk program tanggung jawab sosial BSM Mataram dihimpun oleh BSM Mataram kemudian disalurkan kepada Laznas untuk dikelola oleh Laznas. Dana tersebut akan 
disalurkan oleh Laznas untuk membiayai kegiatan tanggung jawab sosial BSM Mataram. Kegiatan CSR yang dilakukan oleh BSM merupakan perwujudan atas komitmen perusahaan yang teguh dalam menerapkan prinsip-prinsip syariah yang di dalamnya terkandung ajaran untuk membina hubungan yang harmonis dengan masyarakat sekitar. Pelaksanaan program tanggung jawab sosial (CSR) yang dilakukan oleh BSM cabang Mataram sesuai dengan program pelaksanaan Laznas BSM seperti yang di ungkapkan oleh Bapak Rizal selaku Bagian Pelaksana tanggung jawab sosial BSM sebagai berikut:

"Mekanisme pengelolaan,
penghimpunan dan
penyalurannya semua melalui
Laznas, jadi dari cabang-
cabang BSM itu mengajukan
pemohonan ke Laznas terkait
program-program yang ada di
cabang ya..nah itu nanti kalua
sudah disetujui Laznas baru
bisa disalurkan melalui
cabang, programnya harus
sesuai dengan program Laznas
agar bias disetujui"

Pernyataan Bapak Rizal menunjukan bahwa seluruh program pelaksanaan tanggung jawab sosial yang akan di lakukan BSM cabang Mataram harus melalui persetujuan Laznas. Laznas menyetujui program yang selaras dengan program yang ada pada Laznas, seperti program Simpati Umat, program Didik Umat, dan program Mitra Umat (Annual Report Laznas, 2017). BSM mempunyai dua program yaitu BSM mengalir berkah dan CSR BSM. BSM mengalir berkah dilakukan dengan penyaluran dana sosial melalui pemberian beasiswa dan renovasi tempat ibadah. Sedangkan untuk CSR BSM dilakukan dengan penyaluran dana sosial melalui kegiatan keIslaman, sarana dan prasarana pendidikan, sarana dan prasarana masjid/musholla, qurban, kendaraan operasional dan ambulans, santunan, dan kegiatan lainnya.

Program mengalir berkah BSM cabang Mataram temasuk kedalam program Laznas yaitu Didik Umat dan Simpati Umat. Sedangkan CSR BSM cabang Mataram termasuk kedalam program Laznas yaitu Simpati Umat. Program Simpati Umat yang dilakukan oleh Laznas BSM mempunyai pengertian yaitu Program Simpati Umat merupakan program penyaluran dana zakat, infak, shadaqah dalam rangka memperbaiki dan meningkatkan kualitas hidup masyarakat serta bantuan kemanusiaan dunia Islam (Annual Report Laznas, 2017). Program Simpati Umat mempunyai program unggulan yaitu:

a. Bantuan Kesehatan, dimana merupakan program bantuan kepada pihak yang membutuhkan di bidang kesehatan termasuk sarana dan prasarananya.

b. Jum'at Berbagi Berkah, merupakan program santunan kepada para mustahik yang dilaksanakan di hari Jum'at.

c. Kebencanaan dan Lingkungan Hidup, merupakan merupakan program bantuan untuk mengantisipasi kondisi darurat serta aktif mengurangi dampak akibat terjadinya bencana sosial.

d. Program Ramadhan, merupakan program kegiatan Islam yang dilaksanakan pada bulan Ramadhan.

Sebelum melakukan seluruh program tanggung jawab sosial, BSM cabang Mataram terlebih dahulu melakukan survey untuk menentukan apakah lokasi yang direncanakan akan diberikan bantuan tepat sasaran.
"kami kan survey dulu dik..jadi kami survey dulu ke lokasi, melihat bagaimana lokasi tersebut apakah tepat sasaran untuk kami salurkan bantuan dan dana seperti 
https://ejournal.warmadewa.ac.id/index.php/wicaksana

pada tempat penyaluran

hewan qurban, kami masuk

kedalam lingkungan warga

dan mengadakan interview

dengan warga..sama halnya

dengan pemberian santunan

dan renovasi masjid..kami

survey dulu semuanya

setelah cocok, baru kami

menjalankan programnya.."

Berdasarkan pernyataan yang diungkapkan Bapak Rizal, bahwa program CSR BSM cabang Mataram diberikan pada penerima dengan terlebih dahulu melakukakan survey. BSM melakukan survey atau terjun langsung untuk mengetahui bagaimana keadaan dilokasi dan menginterview warga yang berada dilokasi untuk menghimpun data sesuai dengan keadaan tersebut. Dengan memiliki data tersebut BSM dapat menilai dan menyalurkan tepat pada sasaran yang dibutuhkan warga sekitar. Dikarenakan bank syaraiah berlandaskan Al-Qur'an dan Hadits maka setiap kegiatannya juga sudah sebagaimana mestinya menerapkan kegiatan yang halal. Tidak boleh sembarangan memberikan dananya untuk hal yang belum jelas, maka dari itu pihak BSM tidak bisa serta merta memberikan bantuan tanpa melihat bagaimana kondisi dilapangan, agar CSR yang dilakukan dapat tepat sasaran dan bermanfaat untuk lingkungan sekitar.

Program Simpati Umat yang dilakukan BSM Cabang mataram juga ada dalam Bentuk Bantuan Bencana Alam. BSM Cabang Mataram bersama Laznas telah melaksanakan program untuk bencana alam. Seperti pada kejadian gempa Lombok-sumbawa pada tahun 2018, BSM cabang Mataram bersama Laznas turut serta untuk membantu para korban bencana. Hal ini seperti yang dikemukakan oleh pak Rizal sebagai berikut:

$$
\begin{aligned}
& \text { "ya..bencana..gempa } \\
& \text { kemarin, BSM bersama } \\
& \text { laznas juga mengadakan }
\end{aligned}
$$

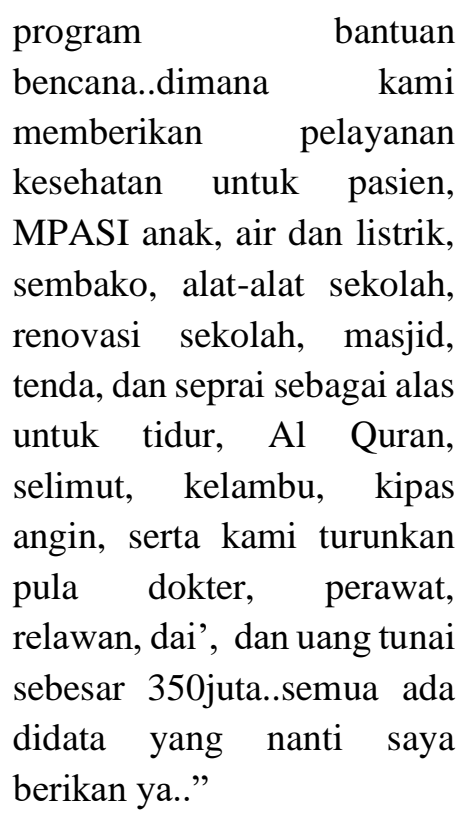

Berdasarkan pemaparan dari Bapak Rizal menunjukan bahwa BSM dan Laznas mengadakan program bantuan bencana alam Lombok-Sumbawa. Bentuk bantuan yang diberikan berupa bantuan pelayanan kesehatan untuk pasien, MPASI anak, air dan listrik, sembako, alat-alat sekolah, renovasi sekolah, masjid, tenda, dan seprai sebagai alas untuk tidur, Al-Qur'an, selimut, kelambu, kipas angin, serta BSM dan Laznas mendatangkan dokter, perawat, relawan, da'i. dan uang tunai sebesar 350 juta.

Program bantuan bencana alam Lombok-sumbawa 2018. Program bantuan CSR BSM tersebut disalurkan pada 23 Dusun di 4 Kabupaten (Lombok barat, timur, KLU dan Sumbawa) dan 13 Dusun di Lombok Utara dan Timur, yaitu berupa pelayanan kesehatan, MPASI, tandon air, pompa air, genzet, 5,5 ton beras, lauk pauk, air mineral, sanitary pack, perlengkapan sekolah, Al quran, selimut, dapur umum, kelambu, kipas angin, serta BSM dan Laznas mendatangkan dokter, perawat, relawan, da'i. dan uang tunai sebesar 350 juta. Adanya bantuan bencana alam yang diberikan oleh BSM akan meningkatkan citra perusahaan atas kepedulian perusahaan atas permasalahan sosial yang ada disekitar wilayah operasionalnya. Tanggung jawab sosial 
dianggap dapat meningkatkan reputasi organisasi.

Program sosial lainnya yang dijalankan oleh BSM cabang Mataram, yaitu Program Ramadhan dan kegiatannya dilaksanakan pada bulan Ramadhan. Menjelang hari raya Idul Adha $1438 \mathrm{H}$ BSM cabang Mataram mengadakan acara potong qurban. Program ini merupakan program tahunan yang dilakukan dalam rangka merayakan hari raya Idul Adha. Program ini diwujudkan dengan kegiatan penyaluran hewan kurban kepada masyarakat yang kurang mampu, yang berlokasi di BSM cabang Mataram. Berikut pernyataan dari Bapak Rizal:

"kami saat hari raya kemarin juga mengadakan potong qurban yang bertempat di BSM sendiri dengan nominal dana 15juta, dengan pembagian mengarah kepada Kaum Dhuafa Sekitar Kantor, Warga Dusun Datar Kelurahan Bengkel Kabupaten Lombok Barat, Dusun Pandan Salas dan Warga Pinggiran Kali Dasan Agung.dan biasanya setiap tahun kami memberikan bantuan qurban tersebut untuk masyarakat yang kurang mampu disekitar kantor atau di desa desa"

Selain program pemotongan qurban, BSM cabang Mataram bersama Laznas juga mengadakan program kegiatan Ramadhan 1439 $\mathrm{H}$ yaitu Santunan Anak Yatim dan Dhuafa dalam rangaka BSM Siaran,

"kami kemarin juga
melaksanakan BSM Siaran
dalam rangka kegiatan
Ramadhan $1439 \mathrm{H}$ bersama
dengan kegiatan pemprov
NTB yang berlokasi di
Masjid Hubbul Wathan, dengan rangkaian kegiatan diawali dengan mendengarkan taushiah serta pengenalan BSM kemudian memberikan santunan kepada 55 anak yatim dan selanjutnya buka puasa bersama dan sholat magrib, untuk dananya sendiri kami mengeluarkan $16.5 \mathrm{jt}$ itu terbagi lagi untuk santunan, iftar+takjil dan transport"

Lanjutnya:

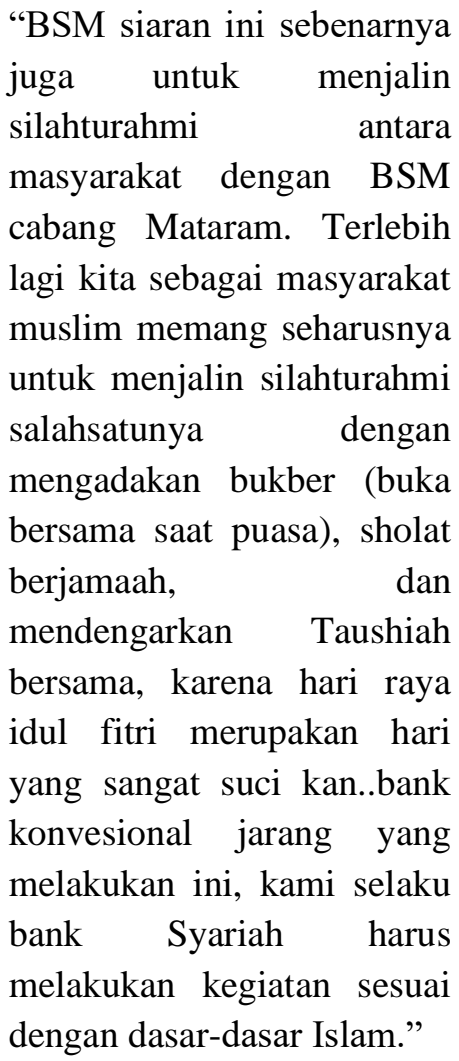

Pernyataan Bapak Rizal mengenai pembagaian hewan qurban yang diberikan untuk masyarakat kaum dhuafa disekitar kantor BSM, yaitu Warga Dusun Datar Kelurahan Bengkel Kabupaten Lombok Barat, Dusun Pandan Salas dan Warga Pinggiran Kali Dasan Agung. BSM memberikan bantuan hewan qurban bertujuan agar dapat membantu masyarakat sekitar yang kurang mampu untuk 
membeli daging qurban untuk hari raya Idul Adha. Tidak hanya untuk hari raya Idul Adha di tahun $1438 \mathrm{H}$, pada tahun sebelumnya BSM bersama Laznas juga melakukan program pelaksanaan pemotongan hewan qurban yang sasaran pembagiannya kepada masyarakat yang kurang mampu.

Berdasarkan pemaparan dari Bapak Rizal, kegiatan hari raya tidak hanya dilakukan pada hari raya Idul Adha saja tapi juga untuk menyambut hari raya Ramadhan. Seperti dalam program BSM Siaran yang dilaksanakan pada Masjid Hubbul Wathan dimana BSM bersama Laznas memberikan santunan kepada anak yatim dan dhuafa. Kegiatan diawali dengan mendengarkan Taushiah, pengenalan tentang BSM, pemberian santunan kepada 55 orang anak yatim dan dhuafa, kemudian dilanjutkan dengan buka puasa bersama serta sholat magrib berjema'ah. BSM cabang Mataram melakukan program bantuan dalam bentuk pembangunan sarana dan prasanana untuk kegiatan keagamaan. Sebagai bagian dari kepedulian pada lingkungan sekitar, BSM Tahun 2017 menggelar program BSM Mengalir Berkah. Program ini berbentuk pemberian dana sosial yang merujuk pada renovasi tempat ibadah atau biaya pemeliharaan tempat ibadah. Perhitungan pemberian dana sosial didasarkan pada Contribution Margin (CM) setiap outlet. Melalui program ini, BSM telah memberikan bantuan kepada lebih dari 400-an masjid yang tersebar di seluruh Indonesia (Annual Report Laznas 2017).

Dalam upaya meningkatkan keimanan dan ketaqwaan masyarakat, BSM juga telah memberikan bantuan untuk kegiatan keagamaan. Bentuk kegiatan keagamaan selama ini banyak yang digunakan untuk renovasi atau perbaikan sarana ibadah. BSM cabang Mataram telah melakukan renovasi masjid berserta tempat wudhu untuk wanita seperti yang diungkapkan oleh Bapak Rizal berikut ini:

"renovasi kemarin kami
lakukan secara dua tahap
yang masing masing
tahapnya 12juta. Renovasi
dilakukan pada tempat
wudhu wanita dan beberapa
bagian masjid yang harus di
cat ulang...Oh lokasinya
sama dengan masjid yang
kami beri santunan untuk
anak yatim dan dhuafa di
Masjid Al Muttaqin
Cakranegara"

Bantuan untuk pembangunan sarana dan prasaran ibadah diungkapkan oleh Bapak Syamsul dan Pak Rusdi sebagai penerima bantuan program CSR BSM Mataram sebagai berikut:

\begin{tabular}{|c|c|}
\hline $\begin{array}{l}\text { ana bantuan dari } \\
\text { ng diberikan } \\
\text { rguna untuk } \\
\text { rena akan dipergu } \\
\text { tuk mere } \\
\text { enara/kubah masjic } \\
\text { emperbaiki tempat } \\
\text { ar jamaah lebih b } \\
\text { ang datang } \\
\text { elaksanakan } \\
\text { rjamaah" } \\
\text { jamsul, Pengurus }\end{array}$ & $\begin{array}{r}\text { ri BSM } \\
\text { sangat } \\
\text { Masjid } \\
\text { gunakan } \\
\text { renovasi } \\
\text { jid dan } \\
\text { at wudu } \\
\text { banyak } \\
\text { untuk } \\
\text { sholat } \\
\text { (Bapak } \\
\text { Masjid }\end{array}$ \\
\hline
\end{tabular}

"Saya sangat bersyukur akan adanya program BSM ini, warga di sini sangat terbantu karena BSM menyediakan $\mathrm{AC}$, karpet, Al'quran, dan banyak lagi yang lainnya untuk di Masjid, Musholla di sini mbak. BSM juga ngasih umroh buat Marbot Masjid di sini. Tuh Bapak Zaenal tahun kemaren umroh. Harapan kami BSM semakin 
jaya”.(Bapak Rusdi, Marbot

Masjid Hubbul Wathan)

Bapak Rizal memaparkan bahwa pembangunan pada Masjid Al Muttaqin Cakranegara melalui dua tahap yaitu pengecatan beberapa sisi masjid dan pembangunan tempat wudhu untuk wanita. Dana sosial yang dikeluarkan untuk dua tahap tersebut masing-masing adalah Rp. 12.000.000. Program bantuan dalam bentuk bentuk pembangunan sarana dan prasarana keagmaan tersebut diharapkan akan dapat memberikan kenyamanan bagi masyarakat untuk melakukan ibadah. Bantuan dalam bentuk kegiatan keagamaan difungsikan untuk meningkatkan keimanan dan ketaqwaan masyarakat disekitar operasional BSM. Dari beberapa contoh bentuk bantuan untuk keagamaan tersebut menunjukan kepedulian perusahaan dalam meningkatkan keimanan dan ketaqwaan masyarakat sekitar BSM. Niat baik BSM tersebut disambut dengan baik oleh masyarakat seperti yang diungkapkan oleh Bapak Syamsul dan Pak Rusdi sebagai penerima bantuan program CSR BSM Mataram.

Bapak syamsul dan Bapak Rusdi menyatakan bantuan dari BSM tersebut sangat bermanfaat bagi masyarakat untuk meningkatkan keagamaan masyarakat di wilayah Mataram. Dana bantuan dari BSM yang diberikan akan dipergunakan untuk merenovasi kubah Majid, memperbaiki tempat wudu dan dengan adanya program CSR BSM masyarakat sekitar merasa sangat terbantu karena BSM menyediakan AC, karpet, Alqur'an, dan bentuk bantuan lainnya untuk mengindahkan Masjid, Musholla disekitar BSM bahkan BSM memberikan hadiah umroh pada taqmir masjid. Dengan adanya bantuanbantuan tersebut dirasa sangat bermanfaat karena masjid menjadi lebih bagus dan lebih nyaman untuk melaksanakan ibadah kepada Allah SWT.

\section{KESIMPULAN}

Tanggung jawab sosial dalam Bank Syariah berbeda dengan Bank Konvesional. tanggung jawab sosial yang dilakukan Bank Syariah melalui dana keuntungan dalam artian untuk zakat, dan dana kebajikan yaitu dana tak bertuan atau dana non halal. BSM cabang Mataram melakukan tanggung jawab sosial yang sumber pendanannya dikelola oleh Laznas (Lembaga Amil Zakat). BSM merealisasi program tanggung jawab sosial perusahaan dengan bekerja sama dengan Laznas. Seluruh program tanggung jawab sosial yang dilakukan harus sesuai dengan program yang dilakukan oleh Laznas.

Pelaksanaan program tanggung jawab sosial yang dilakukan oleh BSM cabang Mataram sesuai dengan program pelaksanaan Laznas BSM. BSM mempunyai dua program yaitu BSM mengalir berkah dan CSR BSM. BSM mengalir berkah dilakukan dengan penyaluran dana sosial melalui pemberian beasiswa dan renovasi tempat ibadah. BSM mengalir berkah temasuk kedalam program Laznas yaitu Didik Umat dan Simpati Umat. Sedangkan untuk CSRl BSM dilakukan dengan penyaluran dana sosial melalui kegiatan keIslaman, sarana dan prasarana pendidikan, sarana dan prasarana masjid/musholla, qurban, kendaraan operasional dan ambulans, santunan, dan kegiatan lainnya. tanggung jawab sosial BSM termasuk kedalam program Laznas yaitu Simpati Umat (Annual Report Laznas, 2017)

Bank syariah mandiri (BSM) cabang Mataram bersama Laznas tahun 2017 hingga 2018 telah melakukan beberapa program tanggung jawab sosial yaitu program Didik Umat, dimana memberikan santunan untuk biaya pendidikan untuk anak yatim dan dhuafa. Selajutnya program Simpati Umat dimana BSM dan Laznas mengadakan program bantuan bencana alam Lombok-Sumbawa. Bentuk bantuan yang diberikan berupa bantuan pelayanan kesehatan untuk pasien, MPASI anak, air dan listrik, sembako, alat-alat sekolah, renovasi sekolah, masjid, tenda, dan seprai 
sebagai alas untuk tidur, Al-Qur'an, selimut, kelambu, kipas angin, serta BSM dan Laznas mendatangkan dokter, perawat, relawan, da'i. dan uang tunai sebesar 350 juta. Serta dalam rangka merayakan hari raya Idul Adha dan Idul Fitri BSM cabang Mataram melakukan pemotongan hewan qurban yang selanjutnya akan diberikan kepada masyarakat sekitar kantor yang kurang mampu. Bank syariah mandiri (BSM) cabang Mataram juga melakukan BSM Siaran dimana terpusatkan untuk memberikan santunan kepada anak -anak yatim yang berada di sekitar Masjid Hubbul Wathan. Program diawali dengan mendengarkan taushiah, pemberian santunan, selanjutnya buka puasa bersama, dan terakhir sholat magrib berjama'ah. Bank syariah mandiri (BSM) cabang Mataram juga melakukan renovasi masjid berserta tempat wudhu untuk wanita.

BSM cabang Mataram telah melaksanakan kegitatan operasional sesuai dengan sistem, norma, nilai dan kepercayaan yang berlaku di masyarakat. BSM cabang Mataram juga telah melaporkan seluruh kegiatan dalam program tanggung jawab sosial yang dijalankan bersama Laznas pada website BSM dan Laznas serta dalam Media Massa seperti koran dan televisi. Pemaparan programprogram tanggung jawab sosial yang telah dilakukan oleh BSM cabang Mataram dapat ditarik kesimpulan bahwa BSM cabang Mataram telah melakukan tanggung jawab sosial terutama lebih mengarah ke segi keIslaman/keagamaan yang mengedepankan nilai-nilai ilahiyah (Syariah). Kegiatan tanggung jawab sosial yang dilaksanakan oleh BSM juga tidak hanya memberikan bantuan dari segi dana untuk meningkatkan citra perusahaan namun juga mempunyai tujuan untuk lebih meningkatkan spiritualitas warga dan meningkatkan kenyamanan warga untuk beribadah serta menjalin silahturahmi antara masyarakat sekitar dengan BSM.

\section{Daftar Pustaka}

Annual Report Laznas, 2017-2018

Anto, H. M.B., dan Astuti, D.R. 2008.

Persepsi Stakeholder Terhadap

Pelaksanaan Corporate Sosial

Responsibility: Kasus Pada Bank

Syariah di DIY. Sinergi, Kajian

Bisnis dan Manajemen, vol. 10 No. 1:

$20-21$.

Djakfar, Muhammad. 2010. Teologi Ekonomi: Membumikan Tintah Langit di Ranah Bisnis. UIN Maliki Press. Malang.

Dusuki, A. W. 2008. Understanding the Objectives of Islamic Banking: A Survey of Stakeholders' Perspectives. International Journal of Islamic and Middle Eastern Finance and Management Vol. 1 Issue: 2, pp.132148.

Erwanda, Edwin. 2012. Tanggung Jawab Sosial Pada Organisasi Perbankan Syariah (Studi Kasus Pada Bni Syariah Cabang Malang). JIMFEB vol 1 No 2.

Haniffa, R. 2002. Sosialreporting disclosure: An Islamic perspective. Indonesian Management and Accounting Research 1 (2) pp 128-146.

Haniffa, R., dan Hudaib, M. 2001. A conceptual framework for Islamic accounting: The Shariah paradigm. International Conference on Accounting, Auditing and Finance. Palmerstone North, New Zealand, Unpublished article.

Isnawati. 2018. Analisis Pengungkapan Tanggung Jawab Sosial Perusahaan Pada Tiga Bank Syariah Di Indonesia. Jurnal Akuntansi UNP vol 6 No 1. 
Kamla, R. 2007. Critically Appreciating

SosialAccounting and Reporting in the Arab MiddleEast: A Postcolonial Perspektive. Advance in International Accounting Vol. 20 pp. $105-177$.

Meutia, Inten. 2010. Menata Pengungkapan CSR di Bank Islam (Suatu Pendekatan Kritis).Jakarta: Citra Pustaka Indonesia.

Miles, B. B,.dan Huberman, A.M. 1992. Analisis Data Kualitatif. Jakarta: UI Press.

Prajarto, N. 2012. Kepedulian dan Tanggung Jawab CSR dari Tumpukan Uang Bank CSR Indonesia Sinergi Pemerintah, Perusahaan dan Publik. Thesis. Fakultas Ilmu Sosial dan Politik Universitas Gajah Mada

Prastowo dan Huda. 2011. Corporate Sosial Responsibility Kunci Meraih Kemuliaan Bisnis.Yogyakarta: Samudra Biru.

Sairally, Salma. 2005. Evaluating the „SosialResponsibility ${ }^{\text {ee }}$ of Islamic Finance: Learning From the Experiences of Sosially Responsible Investment Funds.
Proceeding of The 6th International Confrence on

Islamic Economic and

Finance. Vol.1. Jakarta.

Sayekti dan Wandabio. 2007. Pengaruh CSR Disclosure Terhadap Earning Response Coeffcient. Simposium Nasional Akuntansi X. Makasar.

Siwar, C., \& Hossain, M. T. (2009). An Analysis of Islamic CSR Concept and the Opinions of Malaysian Managers, Management of Environmental Quality: An International Journal, Vol. 20 Issue: 3, pp. 290-298.

Turmudi, M. 2018. Pemanfaatan Dana Corporate Social Responsibility Bank Syariah Mandiri Cabang Kendari. Al Izzah: Jurnal Hasil-Hasil Penelitian-ISSN: $1978-9726$ (p); 2541-0717 (e), Volume 13 , Nomor 1

Wibisono, Y., 2007.Membedah Konsep dan Aplikasi CSR (Corporate Sosial Responsibility). Gresik: Fascho Publishing.

Yusuf, M., Y. 2010. How to Implement Islamic Banking"s CSR in the Society?. Jurnal Ekonomi dan Keuangan Islam, 1(1), 1-15 